\title{
IMPLEMENTASI PEMBELAJARAN BERBASIS E-LEARNING MENGGUNAKAN CLAROLINE
}

\author{
Indah Purnama Sari \\ Dosen Program Studi Pendidikan Ekonomi Universitas Indraprasta PGRI \\ Email : indahps.unindra@gmail.com
}

\begin{abstract}
Abstrak
Globalisasi mengisyaratkan tuntutan bagi masyarakat Indonesia untuk meningkatkan literasi teknologi informasi dan komunikasi (TIK) yang berkualitas dan memiliki kemampuan untuk menggunakannya. Salah satu upaya yang dapat dilakukan oleh dunia pendidikan untuk mampu berkompetisi di era globalisasi adalah dengan mengintegrasikan TIK ke dalam proses belajar.Salah satu bentuk integrasi TIK dalam pembelajaran adalah dengan menggunakan pembelajaran elektronik berbasis internet (e-learning). Claroline adalah salah satu sistem (perangkat lunak) untuk mengelola e-learning. Claroline cukup sederhana, dan intuitif (multibahasa, termasuk bahasa Indonesia) sehingga mudah digunakan oleh pemula.Sebenarnya, hingga saat ini di Indonesia, e-learning tidak bisa sepenuhnya menggantikan aktivitas belajar konvensional di ruang kelas, namun e-learning bisa dijadikan suplemen atau pelengkap pembelajaran. Penggunaan e-learning dalam proses belajar dan pembelajaran memungkinkan terciptanya sumber daya manusia yang mengenal dan mampu berinteraksi serta memanfaatkan teknologi informasi dan komunikasi (internet).
\end{abstract}

Kata kunci:Claroline, e-learning

\section{PENDAHULUAN}

Istilah globalisasi secara popular dapat diartikan menyebarnya segala sesuatu secara sangat cepat ke seluruh dunia.Terjadinya globalisasi memberi dampak ganda, yaitu dampak menguntungkan dan dampak yang merugikan. Dampak yang menguntungkan adalah memberi kesempatan yang seluas-luasnya kepada negara-negara asing, namun disisi lain jika kita tidak mampu bersaing dengan mereka karena lemahnya sumber daya manusia yang ada, maka konsekuensinya akan merugikan bangsa kita. Oleh karena itu tantangan bangsa Indonesia saat ini adalah meningkatkan daya saing dan keunggulan kompetitif maupun komparatif di semua sektor, termasuk di dalamnya sektor pendidikan.

Sektor pendidikan harus mampu menghadapi perubahan yang sangat cepat dan sangat besar dalam tantangan era perdagangan bebas. Dalam hal ini apakah pendidikan mampu menghasilkan lulusan yang berdaya saing tinggi (qualified) sesuai kebutuhan pasar atau justru mandul dalam menghadapi gempuran kemajuan dinamika era perdagangan bebas tersebut. Dengan demikian, era perdagangan bebas adalah tantangan yang besar dalam dunia pendidikan yang harus dijawab dengan kemampuan dunia pendidikan dalam melahirkan manusia-manusia yang berdaya saing tinggi dan tangguh. Salah satu ciri sumber daya manusia (SDM) yang tangguh adalah SDM yang menguasai 
ilmu pengetahuan dan teknologi (IPTEK), maka tugas pendidikan selain mempersiapkan SDM sebagai subyek era globalisasi, juga membina IPTEK.

Pada masa era perdagangan bebas (tahun 2020) masyarakat Indonesia harus memiliki ICT literacy yang mumpuni dan memiliki kemampuan dalam menggunakannya. Salah satu upaya yang dapat dilakukan oleh dunia pendidikan untuk menyikapi era perdagangan bebas adalah mengintegrasikan teknologi informasi dan komunikasi (TIK) ke dalam proses pembelajaran. Pengintegrasian TIK ke dalam proses pembelajaran ini dapat meningkatkan ICT literacy, membangun karakteristik masyarakat berbasis pengetahuan, serta meningkatkan efektifitas dan efisiensi proses pembelajaran itu sendiri.

Salah satu bentuk pengintegrasian TIK dalam pembelajaran adalah pembelajaran berbasis elektronik menggunakan internet (e-learning). Penerapan e-learning sebagai bagian integral dari sistem pembelajaran telah dilakukan oleh beberapa lembaga pendidikan di berbagai negara, seperti Jerman, Italia, Amerika Serikat, Inggris, Perancis, Singapura, termasuk juga Indonesia (Wena, 2009). Perkembangan e-learning yang cukup marak juga terjadi di Australia, sebagaimana data yang dikutip dari https://swa.co.id/swa/listed-articles/ini-era-e-learning-bung (diakses 15 Oktober 2017), menurut Hanny Santoso, praktisi teknologi informasi (TI), Dipicu biaya pelatihan dan tenaga pelatih yang cukup mahal, kini banyak perusahaan beralih ke e-learning, menggunakan pendekatan fully blended learning. Lalu, semua universitas dan perguruan tinggi pun memiliki pusat pengembangan e-learning. Yang tak kalah penting, ada dukungan penuh dari pemerintah. Melalui departemen pendidikan dan perindustrian, pemerintah pusat dan negara bagian memberi dukungan dana puluhan juta dolar untuk berbagai proyek e-learning. Depperindag di Victoria misalnya, memberi akses gratis Learning Management System (LMS) Blackboard yang dipusatkan layaknya sebuah application service provider, sehingga dapat dipakai oleh semua penyelenggara kursus dan institusi pendidikan di Victoria.

Tak hanya itu. Pemerintah Australia juga mengucurkan dana untuk pembuatan ribuan Learning Object ( $L O$ ) dari berbagai mata kuliah yang dapat diakses gratis oleh setiap guru/dosen untuk membuat bahan ajar dalam format e-learning. Dengan adanya LO, mereka tidak perlu lagi membuat ulang bahan yang sudah ada. Institusi tinggal mengambil yang sudah ada di repositori, mengedit dan memperkayanya. Pengembangan bahan diawasi oleh para Certified Instructional Designer dan secara teknis dialihdayakan 
ke perusahaan swasta. Menariknya, repositori LO setiap negara bagian saling terhubung dan dapat diakses (https://swa.co.id/swa/listed-articles/ini-era-e-learning-bung).

Aplikasi e-learning yang lumrah digunakan diantaranya adalah Moodle dan Claroline. Di dalam kajian ini akan dibahas secara lebih mendalam pemanfaatan Claroline dalam pembelajaran sebagai alternatif sumber belajar, media pendidikan jarak jauh, sekaligus sebagai suplemen dan komplemen pembelajaran.

\section{TINJAUAN PUSTAKA}

\section{Teknologi Internet dalam Pendidikan}

Dunia pendidikan terimbas pula oleh pesatnya perkembangan jagat maya. Teknologi internet pada hakikatnya merupakan perkembangan dari teknologi komunikasi generasi sebelumnya. Media seperti radio, televisi, video, multimedia, dan media lain telah digunakan dan dapat membantu meningkatkan mutu pendidikan.

Media internet memiliki sifat interaktif yaitu bisa sebagai media massa dan interpersonal, serta sebagai sumber informasi dari berbagai penjuru dunia. Hal ini sangat memungkinkan media internet menjadi media yang lebih unggul dari generasi sebelumnya. Setelah kehadiran guru dalam arti sebenarnya, internet akan menjadi suplemen dan komplemen dalam mewakilkan guru yang menjadi sumber belajar yang penting di dunia (Tung, 2000). Dahulu proses belajar mengajar didominasi oleh peran guru sementara siswa hanya mendengar penjelasan dari guru, disebut "the era of teacher". Kemudian proses belajar mengajar didominasi oleh peran guru dan buku (the era of teacher and book), dan pada saat ini proses belajar mengajar didominasi oleh peran guru, buku, dan teknologi (the era of teacher, book, and technology) (Sardjana, 2011).

Dengan fasilitas yang dimiliki, beberapa dampak positif penggunaan internet dalam dunia pendidikan yaitu: menjadi akses kepada sumber informasi, akses kepada nara sumber, dan sebagai media kerjasama. Akses kepada sumber informasi yaitu sebagai perpustakaan online, sumber literatur, akses jurnal hasil penelitian, dan akses materi kuliah. Akses kepada nara sumber bisa dilakukannya komunikasi tanpa harus bertemu secara fisik, misalnya layanan konsultasi dengan para pakar. Sedangkan sebagai media kerjasama, internet dapat digunakan untuk melakukan kegiatan penelitian bersama atau membuat makalah bersama. 
Studi lainnya dilakukan oleh Center Of Applied Special Technology (CAST) bahwa pemanfaatan internet sebagai media pendidikan menunjukkan dampak yang positif terhadap hasil belajar peserta didik.

\section{Model Pembelajaran Berbasis Elektronik (E-Learning)}

Pembelajaran e-learning telah diterapkan sejak tahun 1970-an. Pembelajaran $e$ learning merupakan pembelajaran yang memanfaatkan jaringan (internet, LAN, WAN) sebagai metode penyampaian, interaksi, dan fasilitasi serta didukung oleh berbagai bentuk layanan belajar lainnya (Brown dalam Wena, 2009). E-learning adalah sebuah alternatif media pendidikan yang tidak mengenal ruang dan waktu.

Secara umum terdapat beberapa hal penting sebagai persyaratan pelaksanaan $e$ learning, yaitu sebagai berikut:

a. Kegiatan proses pembelajaran dilakukan melalui pemanfaatan jaringan.

b. Tersedianya dukungan layanan tutor yang dapat membantu peserta didik apabila mengalami kesulitan belajar.

c. Adanya lembaga penyelenggara/ pengelola e-learning.

d. Adanya sikap positif dari siswa dan tenaga pendidik terhadap teknologi computer dan internet.

e. Tersedianya rancangan sistem pembelajaran yang dapat dipelajari/ diketahui oleh setiap peserta didik.

f. Adanya sistem evaluasi terhadap kemajuan belajar siswa dan mekanisme umpan balik yang dikembangkan oleh lembaga penyelenggara.

(Waller dan Wilson, 2001).

\section{Tujuan, Manfaat, dan Fungsi Pembelajaran Elektronik}

Tujuan penggunaan e-learning sebagai sistem belajar adalah (Sanaky dalam Chandrawati, 2010) :

1. Meningkatkan kualitas belajar

2. Mengubah budaya mengajar

3. Mengubah budaya belajar yang pasif menjadi budaya belajar yang aktif sehingga terbentuk independent learning

4. Memperluas basis dan kesempatan belajar oleh masyarakat

5. Mengembangkan dan memperluas produk dan layanan baru pembelajaran. 
Pembelajaran elektronik (e-learning) bermanfaat bagi berbagai pihak yang terkait, seperti siswa, guru, bagi sekolah. Dengan kegiatan e-learning dimungkinkan berkembangnya fleksibilitas belajar peserta didik yang optimal, dimana dapat mengakses materi secara berulang serta dapat berkomunikasi dengan tutor/ guru/ dosen tanpa dibatasi ruang dan waktu.

Beberapa manfaat yang dapat dirasakan oleh guru diantaranya lebih mudah melakukan pemutakhiran bahan-bahan ajar, dapat mengembangkan penelitian dan meningkatkan wawasan, dapat mengontrol kebiasaan belajar peserta didik, dapat mengecek tanggung jawab peserta didik dalam menyelesaikan tugas, serta dapat langsung memeriksa dan mengirimkan umpan balik kepada peserta didik.

Dengan adanya model pembelajaran e-learning berbasis web, maka di sekolah atau kampus akan tersedia bahan ajar yang telah divalidasi sesuai dengan bidangnya sehingga setiap pembelajaran di jurusan secara keseluruhan akan semakin efektif dan efisien. Selain itu pengembangan isi pembelajaran akan sesuai dengan pokok-pokok bahasan, juga sebagai pedoman praktis implementasi pembelajaran sesuai dengan kondisi dan karakteristik pembelajaran. Manfaat yang lain adalah akan menumbuhkan sikap kerjasama antar civitas akademika, pengajar, peserta didik, maupun bagian IT.

Setidaknya terdapat tiga fungsi pembelajaran elektronik terhadap kegiatan pembelajaran di dalam kelas, yaitu: sebagai suplemen pembelajaran yang sifatnya pilihan/ opsional,sebagai pelengkap (komplemen) pembelajaran, dan sebagai pengganti (substitusi) pembelajaran. Hal ini jika pembelajaran elektronik sepenuhnya digunakan dalam proses pembelajaran, tanpa menggunakan model pembelajaran lainnya (Siahaan, 2004).

\section{Pengembangan Pembelajaran Berbasis E-Learning}

Pengembangan pembelajaran berbasis e-learning perlu dirancang secara cermat sesuai tujuan yang diinginkan. Menurut Haughey (1998), ada tiga kemungkinan dalam pengembangan sistem pembelajaran berbasis internet, yaitu "web course, web centric course, dan web enhanced course”.

Web course adalah penggunaan internet untuk keperluan pendidikan dimana peserta didik dan pengajar sepenuhnya terpisah, tidak diperlukan adanya tatap muka.Seluruh bahan ajar, diskusi, konsultasi, penugasan, latihan, ujian dan kegiatan pembelajaran lainnya sepenuhnya disampaikan melalui internet (sistem pembelajaran jarak jauh). 
Web centric course adalah penggunaan internet yang memadukan antara belajar tanpa tatap muka (jarak jauh) dan tatap muka (konvensional).Sebagian materi disampaikan melalui internet, dan sebagian lagi melalui tatap muka, dimana fungsinya saling melengkapi.

Web enhanced course adalah pemanfaatan internet untuk menunjang peningkatan kualitas pembelajaran yang dilakukan di kelas. Peran pengajar dalam hal ini dituntut untuk menguasai teknik browsing, mengetahui situs-situs yang relevan, menyajikan materi secara menarik melalui web, melayani bimbingan melalui internet, dan sebagainya.

Pengembangan e-learning selain menyajikan materi secara online juga harus komunikatif dan menarik. Untuk dapat menghasilkan e-learning yang menarik setidaknya harus memenuhi tiga syarat yaitu: sederhana, personal, dan cepat (Purbo, 2001). Syarat sederhana merujuk pada mudahnya penggunaan sistem e-learning, syarat personal berarti pengajar berinteraksi dengan baik seperti layaknya tatap muka di kelas, peserta didik dibantu dan diperhatikan kemajuannya. Kemudian layanan ini ditunjang oleh kecepatan dalam memberikan respon terhadap keluhan dan kebutuhan peserta didik.

\section{Pengembangan E-Learning yang Adaptif}

Sebagaimana pembahasan di atas, tujuan umum dari platform pendidikan adalah untuk memberi informasi kepada siswa dan membantu peserta didik memperoleh keterampilan tertentu. Selain itu, untuk meningkatkan pengetahuan tentang topik yang dipelajari yang digali secara aktif.

Namun,setiap peserta didik adalah manusia yang unik. Pelajar yang berbeda mungkin memiliki karakteristik yang berbeda. Karakteristik ini bisaberdasarkan pengetahuan sebelumnya, motivasi atau kebutuhan, hingga gaya belajar. Keanekaragaman ini umumnya membutuhkan penyajian informasi yang berbeda untuk pelajar yang berbeda dalam format yang berbeda pula. Itulah mengapa sangat penting untuk mengembangkan sistem pendidikan adaptif yang mempertimbangkan berbagai aspek individu siswa dan menyesuaikan proses pembelajaran untuk memenuhi kebutuhan aktual siswa (Kareal, Klema, 2006).

Adaptivitas membuat bagian penting dari setiap proses pendidikan yang efektif, oleh karena itu konsep adaptivitas juga harus diimplementasikan dalam sistem e-learning. Berdasarkan penelitian Kareal dan Klema, Claroline termasuk e-learning yang adaptif, 
namun mereka lebih merekomendasikan untuk menggunakan Moodle dibandingkan Claroline. Moodle dianggap yang terbagus (Kareal, Klema, 2006).

\section{Pengembangan E-Learning Berbasis Web dengan Prinsip E-Pedagogi}

Adanya e-learning tentu akan memberikan dampak kepada pengajar baik di dalam menyiapkan materi ajar, metode mengajar, maupun model pembelajarannya. Di dalam menyiapkan materi ajar, pada saat ini seorang pengajar diberi peluang untuk dapat memanfaatkan internet dalam rangka menghasilkan suatu materi ajar yang lebih berkualitas. Di dalam metode mengajar pun seharusnya guru sudah menggunakan metode yang lebih interaktif yang benar-benar dapat menempatkan pembelajaran yang berpusat pada siswa (students-centered). Demikian juga dengan model pembelajaran, perlu disesuaikan dengan keterkinian karakteristik siswa dan keterkinian perangkat yang dapat digunakan.

Berkaitan dengan apa yang diuraikan di atas, George Siemen (dalam Wijaya, 2012) memperkenalkan teori pedagogi connectivism. George memadukan teori belajar behaviorisme dan konstruktivisme pada pembelajaran e-learning. Connectivism yang dikemukakan George mengungkapkan pengetahuan dan pembelajaran sebagai suatu jejaring yang terdiri dari simpul-simpul yang saling berhubungan. Belajar menurut connectivisim adalah penciptaan simpul-simpul dan keterhubungan setiap simpul-simpul tersebut.

Menurut George (2004) dalam (Wijaya, 2012) di dalam teori connectivism, ada delapan prinsip e-pedagogis :

1. Pembelajaran dan pengetahuan berada dalam keanekaragaman (diversity) pandangan/pendapat/opini.

2. Pembelajaran merupakan suatu proses menghubungkan sumber-sumber informasi terutama simpul-simpul khusus.

3. Pembelajaran dapat terjadi dari sesuatu di luar manusia.

4. Kemampuan untuk memahami adalah lebih penting daripada apa yang dipahami sekarang.

5. Menjaga kesinambungan dalam belajar sangat diperlukan untuk kelanjutan pembelajaran.

6. Kemampuan untuk melihat hubungan diantara ide dan konsep sebagai suatu ketrampilan inti dalam pembelajaran. 
7. Keterkinian (keakuratan, pengetahuan mutakhir, up to date) adalah sesuatu yang utama di dalam belajar

8. Pengambilan keputusan dalam memilih apa yang akan dipelajari sangat penting dalam proses pembelajaran dalam menghadapi banjir informasi.

\section{Claroline (Class Room Online)}

Claroline merupakan software opensource yang digunakan untuk pembelajaran secara online. Claroline tersedia dalam banyak bahasa dan bisa didownload serta diinstal secara gratis. Claroline adalah proyek non profit yang dikembangkan oleh UC Louvain (Belgium) pada tahun 2001. Proyek ini sekarang dipimpin oleh Konsorsium Claroline yang menyatukan institusi dari beberapa Negara. Dasar model pembelajaran menggunakan Claroline adalah model pengajaran yang fleksibel, bahwa informasi berubah menjadi pengetahuan melalui kegiatan dan keakifan dari peserta didik dalam sistem yang didorong oleh motivasi dan interaksi. Berbagai macam tools yang terdapat di dalamnya memungkinkan setiap pengajar atau peserta didik untuk membuat atau mengoperasikannya. Diantaranya adalah kalender, dokumen, forum, alur pembelajaran dan dapat disesuaikan dengan konteks pembelajaran yang dibutuhkan (Purwandani, 2016).

\section{PEMBAHASAN}

\section{Implementasi Claroline}

Claroline (Class Room Online) adalah sebuah sistem (software) untuk mengelola elearning, sederhana, dan antarmuka bersifat intuitif (multibahasa, termasuk bahasa Indonesia) sehingga mudah digunakan oleh pemula. Claroline berbasis Web, PHP, dan MySQL, dikeluarkan dibawah lisensi Open Source sehingga dapat didownload secara gratis dari lokasi URL http://www.claroline.net. Claroline saat ini dikembangkan oleh ECAM dan Institut Superieur Industriel dari Belgia. Pengembangan Claroline didukung oleh komunitas pengembang dan pengguna, serta telah dipakai oleh lebih dari 700 lembaga dari 78 negara (Sahid, 2007).

Pemanfaatan Claroline dapat mengembangkan otonomi pedagogi pengajar, yaitu memberikan kesempatan pengajar bereksperimen, menemukan kebutuhan-kebutuhan dalam pedagogi dan mengembangkan pedagogi dalam pengajaran di kelas. Claroline juga 
sebagai media penyampaian materi pembelajaran dan informasi, sebagai sarana pendukung aktivitas belajar peserta didik dan menunjukkan kompetensinya, serta sebagai sarana interaksi antar peserta didik dan pengajar. Claroline mendukung pelaksanaan pembelajaran konvensional, memfasilitasi peserta didik untuk belajar mandiri, serta belajar jarak jauh. Dengan menggunakan Claroline, dimungkinkan untuk dilaksanakannya pembelajaran berbasis masalah dan proyek, dengan penekanan pada cooperative learning. Selain itu pembelajaran ini mendukung evolusi pengajar sebagai katalisator dalam inovasi pedagogi dan pengembangan staf (IT).

Model pedagogi e-learning Claroline menggunakan pendekatan konstruktivisme (socio-constructivism). Informasi ditransformasi menjadi pengetahuan melalui aktivitas peserta didik dan selanjutnya pengetahuan baru digunakan dalam proses berikutnya (pengulangan sistematis). Proses berjalan dengan didukung faktor-faktor motivasi dan dipertahankan melalui interaksi antara lingkungan belajar e-learning, peserta didik, dan pengajar.

Beberapa keuntungan menggunakan e-learning Claroline diantaranya adalah gratis, antarmuka sederhana, multibahasa, termasuk bahasa Indonesia, menggunakan menu/ fasilitas kelas online standar (pengajar tidak perlu merancang menu), pengajar dapat memilih fasilitas kelas online yang ada untuk dimatikan atau diaktifkan, serta tersedia fasilitas pengelolaan isi (content authoring/ management). Dalam proses perkembangannya, beberapa kekurangan pada Claroline diantaranya: belum menyediakan fasilitas pengolahan nilai otomatis (gradebook), belum menyediakan fasilitas video conference, dan pengiriman file satu demi satu, jika ingin mengirim beberapa file sekaligus harus di zip kemudian dikirim ke kelas online setelah itu di unzip.

Berikut ini beberapa contoh tampilan pembelajaran ekonomi menggunakan Claroline (dokumentasi penulis, (Sari, 2012)) dan penjelasan beberapa menu yang digunakan:

1. Tampilan halaman depan (e-learning mata kuliah Pengantar Teori Ekonomi Mikro). Menu e-learning Claroline terdiri dari : halaman depan, deskripsi mata kuliah, agenda, pengumuman, dokumen, latihan-latihan, alur pembelajaran, tugas-tugas, kelompokkelompok, users, wiki, dan diskusi. Dosen memiliki kebebasan dalam menggunakan menu-menu sesuai dengan kebutuhan dan tujuan pembelajaran. 


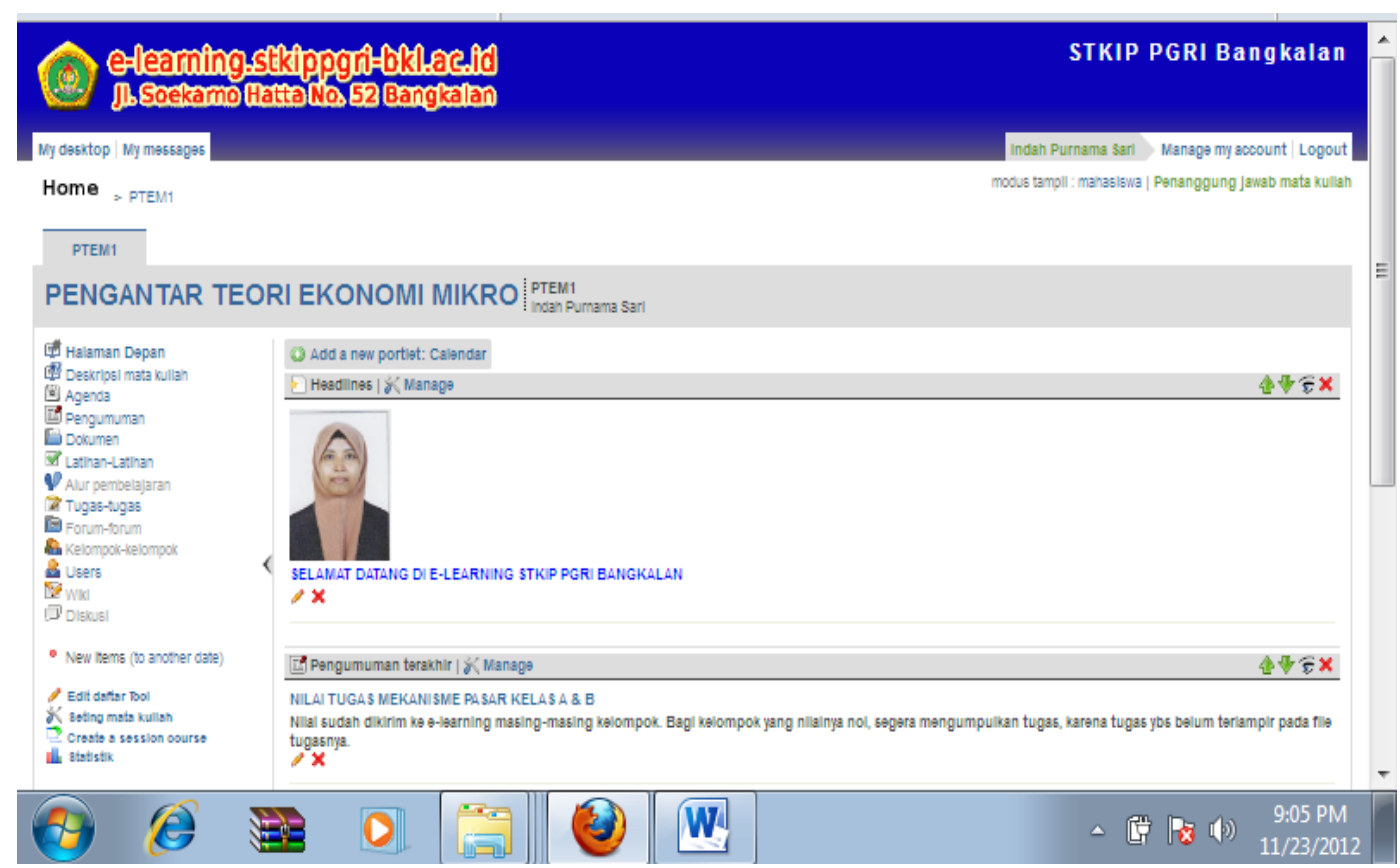

Gambar 1.Tampilan Halaman Depan

2. Menu Deskripsi Mata Kuliah

Menu deskrispsi mata kuliah yang harus diisi meliputi: deskripsi mata kuliah, kualifikasi dan tujuan, isi mata kuliah, kegiatan pembelajaran, Sumber Daya Manusia dan fisik, serta metode evaluasi.

3. Tampilan Dokumen (materi kuliah)

Dokumen materi kuliah diupload sebelum tatap muka berlangsung sehingga mahasiswa dapat mengakses lebih awal untuk dipelajari secara mandiri. Dosen dapat mengatur boleh tidaknya diakses melalui icon "nampak/sembunyi”. Dokumen dapat berupa word document, excel, powerpoint, maupun video. 


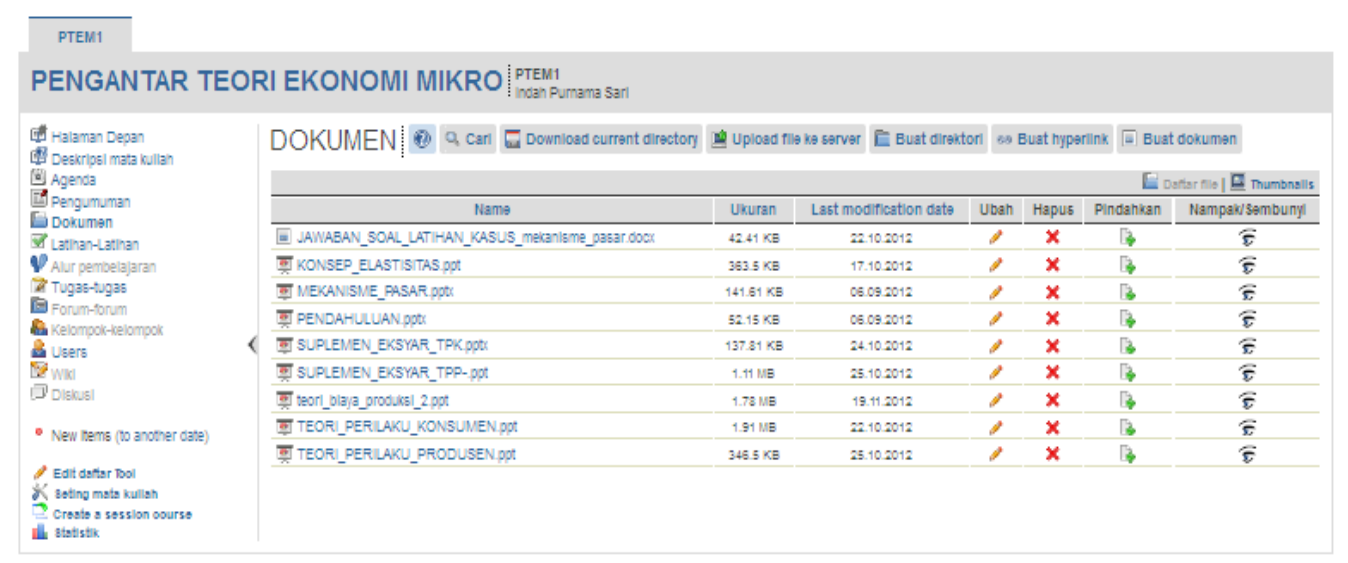

Desain oleh Zaeni Miftah $2010 \cdot 2012$

\section{Gambar 2.Tampilan Dokumen}

4. Tampilan Tugas (mengoreksi jawaban dari mahasiswa, dan mengirimkan umpan balik)

Mahasiswa mengirimkan tugasnya dalam bentuk file pada tenggang waktu yang telah ditentukan dalam e-learning. Setelah kiriman jawaban diterima, dosen dapat langsung mengoreksi serta mengirimkan nilai melalui icon "tambah umpan balik" yaitu dengan mengisi skor nilai mahasiswa.

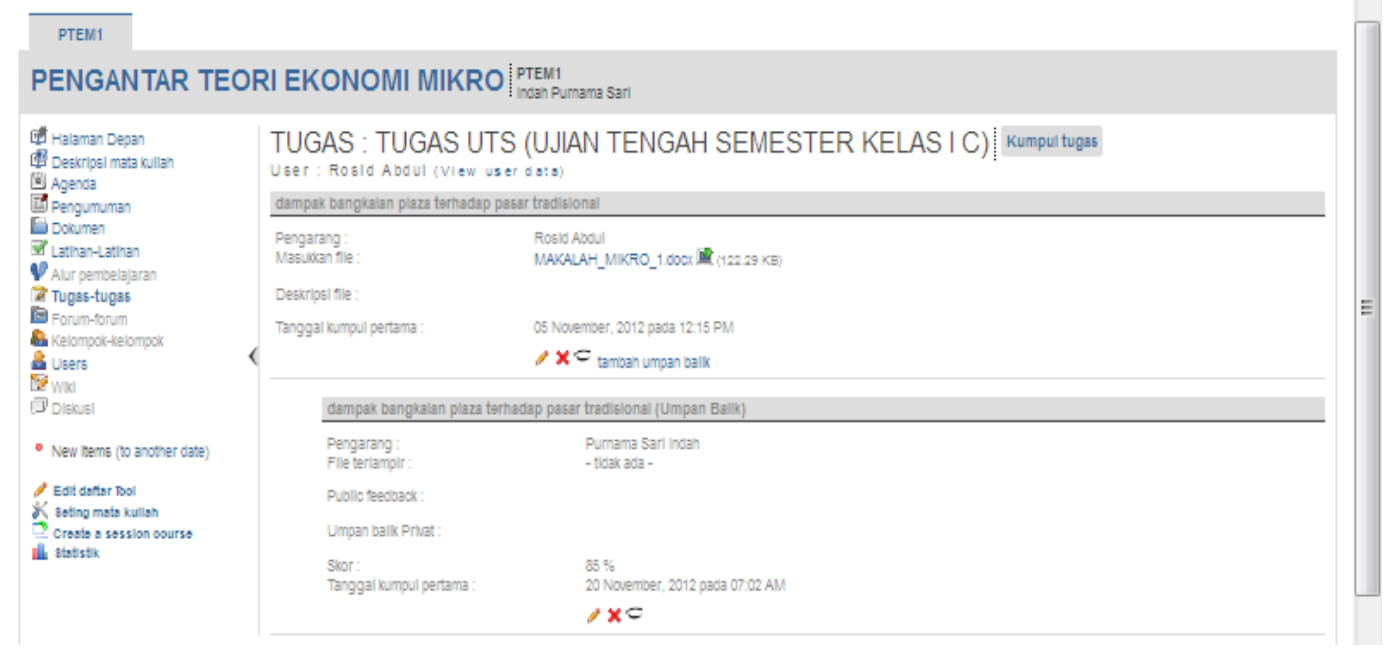

Gambar 3.Tampilan Tugas

Mahasiswa memberikan tanggapan positif saat e-learning diimplementasikan. Mahasiswa bisa mendownload materi, dan berkomunikasi (chatting) dengan sesama mahasiswa yang menjadi anggota grup (kelas e-learning) tersebut. 
Proses evaluasi (post tes) merupakan proses yang paling disukai, di mana mahasiswa mengerjakan tes harus tepat pada jadwal yang telah diumumkan, serta mereka dibatasi oleh waktu (timer) yang berhitung mundur. Mahasiswa juga bisa lebih cepat mengetahui nilainya dibandingkan dengan metode evaluasi tradisional. Hal ini karena koreksi tidak dilakukan secara manual, namun by system. Bentuk soal yang dapat dikoreksi langsung oleh system adalah pilihan ganda, atau pilihan benar dan salah.

\section{SIMPULAN}

Realitanya e-learning belum bisa sepenuhnya menggantikan kegiatan pembelajaran konvensional di kelas, namun e-learning dapat dijadikan suplemen maupun komplemen pembelajaran. Pemanfaatan e-learning dalam pembelajaran memungkinkan terciptanya sumber daya manusia yang mengenal serta mampu berinteraksi serta memanfaatkan teknologi informasi dan komunikasi (internet) sebagai bekal untuk mempersiapkan diri menuju era perdagangan bebas. Dengan demikian sektor pendidikan telah melakukan suatu upaya dalam melahirkan generasi bangsa yang unggul dan tangguh utamanya dalam penguasaan ilmu pengetahuan dan teknologi.

\section{REKOMENDASI}

E-learning perlu mengadaptasi unsur-unsur yanag biasa dilakukan dalam sistem pembelajaran konvensional, misalnya perumusan tujuan yang dapat diukur, pretest, membangkitkan motivasi, komunikatif, uraian materi jelas, problem solving, tanya jawab dan diskusi, post test, penugasan, dan kegiatan tindak lanjut. Oleh karenanya dalam merancang pengembangan e-learning perlu melibatkan pihak terkait, seperti pengajar, ahli materi, ahli IT, ahli komunikasi, dan sebagainya. Namun saat ini sudah tersedia $e$ learning yang siap pakai dan mudah digunakan diantaranya adalah Claroline. Oleh karena itu yang dibutuhkan untuk menyambut era perdagangan bebas adalah kemauan, kesungguhan dan kerjakeras para pengajar (guru, dosen) untuk memanfaatkan e-learning sebagai penunjang pembelajaran di kelas agar peserta didik mengenal serta mampu memanfaatkan kecanggihan teknologi. Dengan demikian akan tercetak peserta didik yang mampu beradaptasi dengan ketatnya kompetensi di era perdagangan bebas, bukan justru tergilas oleh pesatnya kemajuan teknologi. 


\section{DAFTAR PUSTAKA}

Chandrawati, Sri Rahayu. (2010). Pemanfaatan E-Learning dalam Pembelajaran. Jurnal Cakrawala Kependidikan. Vol 8 Nomor 2 September 2010: 101-203.

https://swa.co.id/swa/listed-articles/ini-era-e-learning-bung (diakses 15 Oktober 2017).

Kareal, F.and J. Klema. (2006). Adaptivity in e-learning. Current Developments in Technology-Assisted Education. Semanticscholar.org.

Purbo, Onno W. (2001). Masyarakat Pengguna Internet di Indonesia. http://www.geocities.com.

Purwandani, Indah. (2016). Pengembangan Elearning Berbasis Claroline untuk Pembelajaran PTIK. Prosiding KNIT 2 Vol 2 No 12016.

Sahid. (2007). Mengelola E-Learning dengan Claroline. Makalah disampaikan pada Workshop E-Learning Jurdik Kimia FMIPA UNY.

Sardjana, Djaja. (2011). Hubungan antara Kebutuhan Bisnis, Budaya dan Kemudahan Pengguna Sistem E-Learning. Ekonomi.kompasiana.com

Siahaan, S. (2004). E-Learning (Pembelajaran Elektronik) Sebagai Salah Satu Alternatif Pembelajaran.http://www.depdiknas.go.id.

Tung, Khoe Yao. (2000). Pendidikan dan Riset di Internet. Jakarta: Dinastindo.

Waller, V \&Wilson, J. 2001.A Defenition for E-Learning.The ODL QC Newsletter.

Wijaya, Muksin. (2012). Pengembangan Model Pembelajaran e-Learning Berbasis Web dengan Prinsip e-Pedagogy dalam Meningkatkan Hasil Belajar. Jurnal Pendidikan Penabur - No.19/Tahun ke-11/Desember 2012.

Wena, Made. (2009). Strategi Pembelajaran Inovatif Kontemporer. Jakarta: Bumi Aksara. 